\title{
APPLICATION OF THE FUZZY METHOD IN THE DECISION SUPPORT SYSTEM OF EMPLOYEES RECEIVER IN BNI SYARIAH (PENERAPAN METODE FUZZY PADA SISTEM PENDUKUNG KEPUTUSAN PENERIMAAN PEGAWAI DI BNI SYARIAH)
}

\author{
Fajrul Islami \\ Fakultas Ilmu Kompter, Universitas Putra Indonesia YPTK Padang, Jl. Raya Lubuk Begalung \\ email: fajrul_islami@upiyptk.ac.id
}

\begin{abstract}
Abstrak
Bank Negara Indonesia Syariah merupakan salah satu Badan Usaha Milik Negera yang bergerak dibidang perbankan khususnya perbankan syariah. Dalam hal pemilihan pegawai BNI Syariah secara rutin melakukan perekrutan pegawa setiap tahunnya guna mendukung kegiatan operasional dan pelayanan kepada nasabah. Pelayanan yang terbaik tentu menjadi prioritas utama dalam menjaga kenyamanan dan loyalitas nasabah. Oleh karena itu, dalam upaya menjaga persaingan dibidang keuangan perbankan dan pelayanan nasabah perlu didukung oleh sumber daya manusia yang berkualitas. Didalam melakukan perekrutan pegawai perusahaan memiliki kriteria-kriteria yang sudah ditentukan untuk memastikan bahwa setiap pegawai yang diterima sesuai dengan kebutuhan dari perusahaan. Oleh sebab itu, untuk membantu dalam pemilihaan pegawai yang cepat dan efektif, sistem pendukung keputusan dapat menjadi pilihan dalam meemilih pegawai yang terbaik. Metode Fuzzy merupakan salah satu metode yang dapat digunakan dalam membantu pemilihan pegawai pada BNI Syariah. Dengan menggunakan metode Fuzzy pada Sistem Pendukung Keputusan maka penentuan pegawai yang akan diterima dapat diproses berdasarkan kriteria-kriteria yang sudah ditentukan, sehingga dapat membantu perusahaan memilih pegawai secara cepat dan efektif.
\end{abstract}

Keywords: Sistem Pendukung Keputusan, Penerimaan Pegawai, Fuzzy, Tahani

\section{PENDAHULUAN}

Sumber daya manusia merupakan salah satu aspek terpenting dalam suatu perusahaan. Dimana merupakan penunjang untuk mencapai tujuan dari sebuah perusahaan [1]. Pada era yang penuh dengan persaingan saat ini tentu sebuah perusahaan membutuhkan sumber daya manusia yang tidak hanya mampu menjalankan tugas dan tanggung jawab akan tetapi juga memiliki kemampuan untuk memberikan inovasi dan kreasi untuk kemajuan perusahaan sekarang dan masa yang akan datang. Bank Negara Indonesia Syariah sebagai lembaga keuangan yang tidak hanya membantu mengelola dana pemerintah tapi juga mengelola dana dari masyarakat. Oleh sebab itu, dalam penerimaan pegawai BNI Syariah perlu melakukan penyeleksian dengan menentukan kriteria-kriteria yang sesuai dan dibutuhkan oleh prusahaan.
Dalam kondisi ini sistem pendukung keputusan bisa menjadi pilihan yang terbaik dalam membantu perusahaan menentukan siapa saja karyawan yang dapat diterima sesuai dengan kriteria yang diinginkan perusahaan. Dalam sistem pendukung keputusan dapat diterapkan metode yang mampu memberikan keputusan yang terbaik dari beberapa kriteria yang digunakan. Pada penelitian ini metode yang digunakan adalah metode Fuzzy Tahani. Dimana pada metode ini akan diinputkan kriteria-kriteria yang digunakan untuk seleksi penerimaan pegawai dan berdasarkan data tersebut akan membantu pengambilan keputusan sehingga memiliki penilaian yang sama terhadap semua calon pegawai. Kemudian Fuzzy Tahani mampu melakukan pencarian dalam waktu yang singkat dan memberikan informasi prioritas berdasrkan rule yang tersimpan [2]. Berdasarkan 
kriteria-kriteria yang telah ditentukan nantinya aplikasi akan menganalisa datadata calon pegawai yang sudah ada. Dengan logika Fuzzy, data akan dikelompokkan ke dalam beberapa himpunan Fuzzy sesuai dengan himpunan Fuzzy yang akan diolah sifat kelekatan data, pada himpunan Fuzzy ini bersifat linier atau eksponensial, tergantung dari fungsi keanggotaan Fuzzy yang dipilih.

\section{METODE PENELITIAN}

Desain penelitian yang dikembangkan dalam sistem pendukung keputusan penerimaan pegawai BNI Syariah dengan metode Fuzzy Model Tahani adalah sebagai berikut :

Identifikasi Ruang Lingkup Masalah

Ruang lingkup masalah yang diteliti harus ditentukan terlebih dahulu karena tahapan identifikasi masalah dimulai dengan mempelajari mulai dari mendaftarnya calon pengawai, kemudian analisa hasil Intial Interview, Tes Psikotes, Tes Kesehatan, Interview Akhir.

Pengumpulan Data

Pengumpulan data dan informasi pada tahap ini dilakukan untuk mengetahui sistem yang diteliti. Dari data dan informasi yang dikumpulkan akan didapat data untuk pendukung penelitian, antara lain :

a. Initial Interview

b. Tes Psikotes

c. Tes Kesehatan

d. Interview Akhir

Analisis Sistem

Analisis sistem dapat didefenisikan sebagai penguraian dari suatu sistem informasi yang utuh kedalam bagianbagian komponennya dengan maksud untuk mengidentifikasi dan mengevaluasi permasalahan-permasalahan, kesempatankesempatan, hambatan-hambatan yang terjadi dan kebutuhan-kebutuhan yang diharapkan sehingga dapat diusulkan perbaikan-perbaikannya.
Konsep Model Fuzzy Tahani

Salah satu mekanisme untuk menyelesaikan masalah fuzzy tahani adalah dengan mengaplikasikan metode untuk melakukan penilaian, Apabila data fuzzy diberikan dalam bentuk linguistic, maka harus dikonversi terlebih dahulu ke bentuk bilangan fuzzy, baru kemudian dikonversi kembali ke bilangan crisp [6]. Pengimplementasian metode fuzzy tahani ini ke dalam sistem penerimaan pegawai untuk penilaian calon pegawai baru dilakukan dengan langkah-langkah sebagai berikut :

1. Menentukan kriteria-kriteria yang akan dijadikan acuan dalam penerimaan pegawai baru. Kriteria-kriteria itu terdiri dari nilai IPK, Initial Interview, Psikotes, Tes Kesehatan, Interview Terakhir.

2. Memberikan nilai kepada calon pegawai pada setiap kriteria yang sudah ditentukan, dimana nilai tersebut merupakan bilangan fuzzy yang dikonversikan ke bilangan crisp. Untuk mendapatkan nilai crisp dari bilangan fuzzy yaitu melalui serangkaian tiga proses pada sistem berbasis aturan fuzzy yaitu fuzzyfication, inference rule dan deffuzification. Pada proses inference menggunakan model tahani dan proses defuzzification menggunakan metode weighted average sehingga dari proses ini menghasilkan crisp value.

3. Memberikan nilai bobot setiap kriteria berdasarkan keputusan pengambil keputusan penerimaan pegawai baru.

4. Hasil akhir diperoleh dari proses penegasan dengan metode fuzzy logic tahani, sehingga diperoleh calon pegawai yang akan diterima [7].

Pengujian Sistem

Pengujian sistem dilakukan dalam bentuk konsep dari perancangan sistem pendukung keputusan dalam memilih calon taruna yang tepat, sesuai dengan ketentuan dari BNI Syariah. Implementasi Sistem 
Pada tahap ini dilakukan pengkajian kembali kelayakan dari pada sistem pendukung keputusan yang telah dirancang. Apakah sistem tersebut sudah sesuai atau masih perlu dilakukan peninjauan kembali atau dilakukan perbaikan..

\section{HASIL DAN PEMBAHASAN}

Pada tahap ini akan dilakukan pengolahan data menggunakan metode fuzzy tahani. Adapun tahapan pengolahan datanya yaitu analisa kebutuhan, menentukan fungsi keanggotaan setipa kriteria, dan tahap fuzzyfikasi.

Analisa Kebutuhan

Analisa kebutuhan merupakan langkah awal untuk menentukan pembuatan sistem seperti apa yang akan harapkan, ketika melaksanakan sebuah pembuatan perangkat lunak. Perangkat lunak yang baik dan sesuai dengan kebutuhan pengguna sangat bergantung kepada keberhasilan dalam melakukan analisa kebutuhan.

Kebutuhan Input

Kebutuhan input sistem seleksi penerimaan taruna baru Akademi Angkatan Laut (AAL) digolongkan menjadi 2 yaitu input fuzzy dan input non fuzzy.

Input fuzzy, terdiri dari

a. Data-data calon pegawai yang menyangkut: Nilai IPK, tinggi badan, usia.

b. Data-data Initial Interview yaitu penampilan, wawasan, karakter.

c. Data-data Interview Akhir yaitu penampilan, wawasan, karakter.

Input non fuzzy terdiri dari :

a. Data-data psikotes itelegency, minat, bakat, kepribadian.

b. Data-data test Kesehatan yaitu tes kesehatan jasmani, tes kesehatan rohani, tes kesehatan bebas narkotika.

\section{Kebutuhan Output}

Output sistem berupa kelulusan setiap tahapan tes sesuai denga kriteria yang diinginkan oleh BNI Syariah.

\section{Fungsi Keanggotaan}

\section{Fungsi Keanggotaan Nilai IPK}

Untuk variable Nilai IPK dikategorikan dalam himpunan fuzzy rendah, sedang dan tinggi. Untuk himpunan fuzzy rendah dan tinggi menggunakan pendekatan fungsi keanggotaan yang berbentuk bahu sedangkan untuk himpunan sedang menggunakan pendekatan fungsi keanggotaan yang berbentuk segitiga, seperti yang terlihat pada gambar 1 .

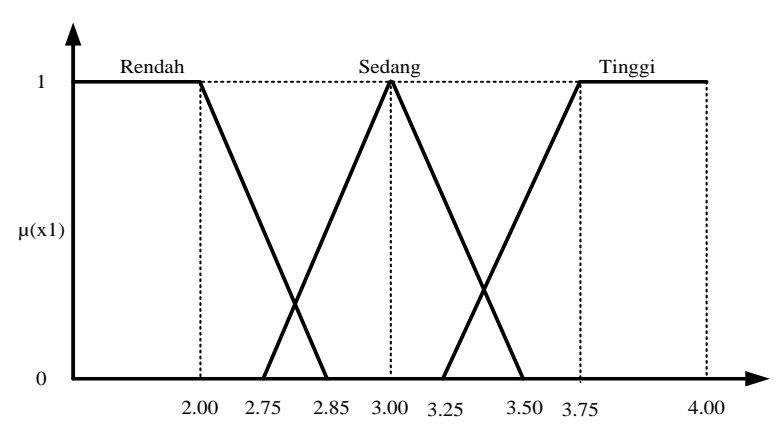

\section{Gambar 1 : Fungsi Keanggotaan Untuk Variabel Nilai IPK}

Fungsi Keanggotaan Tinggi Badan

Untuk variabel tinggi badan dikategorikan dalam himpunan fuzzy rendah, sedang, tinggi. Untuk himpunan fuzzy rendah dan tinggi menggunakan pendekatan fungsi keanggotaan yang berbentuk bahu sedangkan untuk himpunan sedang menggunakan pendekatan fungsi keanggotaan yang berbentuk segitiga, seperti yang terlihat pada gambar 2 . 


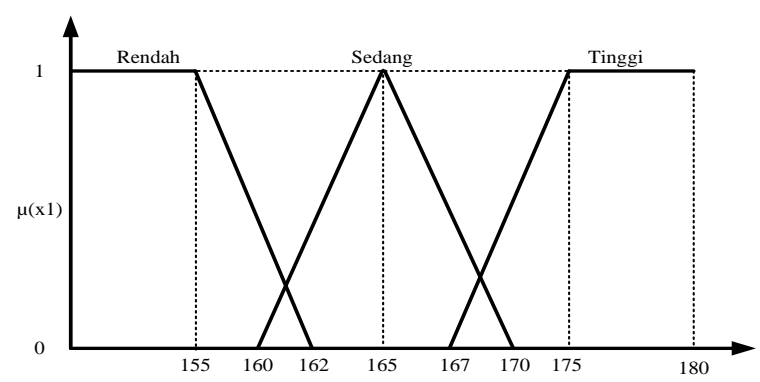

\section{Gambar 2 : Fungsi Keanggotaan Untuk Variabel Tingi Badan}

Fungsi Keanggotaan Umur

Untuk variable umur dikategorikan dalam himpunan fuzzy sangat muda, cukup muda, dan muda. Untuk himpunan fuzzy sangat muda dan muda menggunakan pendekatan fungsi keanggotaan yang berbentuk bahu sedangkan untuk himpunan cukup muda menggunakan pendekatan fungsi keanggotaan yang berbentuk segitiga, seperti yang terlihat pada gambar 3 .

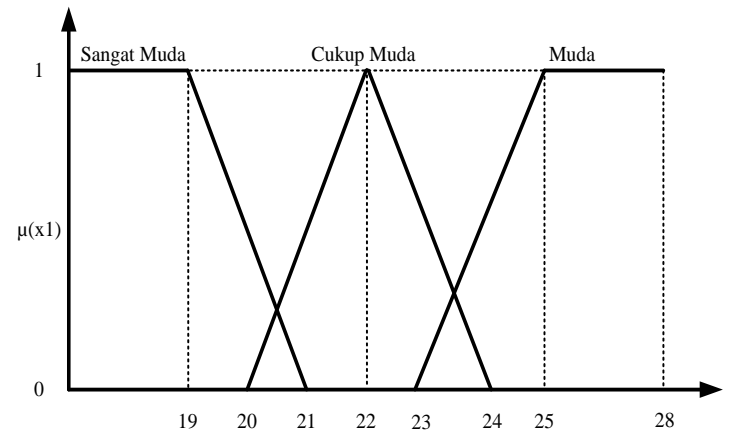

\section{Gambar 3 : Fungsi Keanggotaan Untuk Variabel Usia}

Fungsi Keanggotaan Initial Interview Untuk variabel initial interview dikategorikan dalam himpunan fuzzy rendah, sedang, tinggi. Untuk himpunan fuzzy rendah dan tinggi menggunakan pendekatan fungsi keanggotaan yang berbentuk bahu sedangkan untuk himpunan sedang menggunakan pendekatan fungsi keanggotaan yang berbentuk segitiga, seperti yang terlihat pada gambar 4.

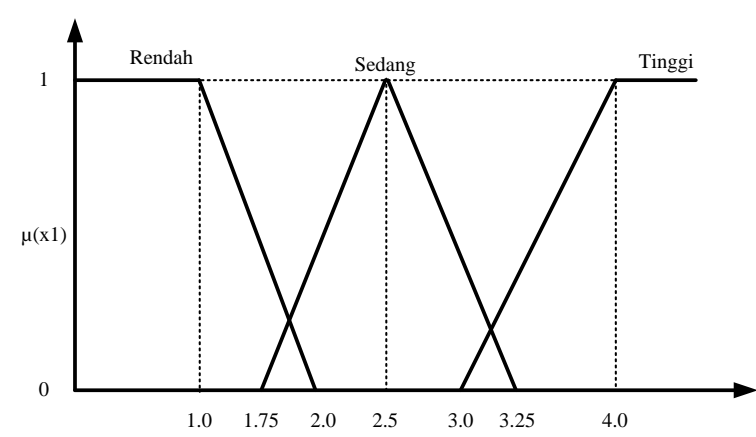

\section{Gambar 4 : Fungsi Keanggotaan Untuk Variabel Initial Interview}

Tahap Fuzzyfikasi

Tahap 1 : Fuzzyfikasi

1. Variabel Indeks nilai IPK= 2.9 termasuk dalam keanggotaan Sedang dengan perhitungan:<smiles>CCCC(CC)CCC</smiles>

$\mu$ Sedang $[\mathrm{x} 1]=0.15 / 0.75$

$\mu$ Sedang $[\mathrm{x} 1]=0.20$

2. Variabel Tinggi Badan $=160$ termasuk dalam keanggotaan Sedang dengan perhitungan:

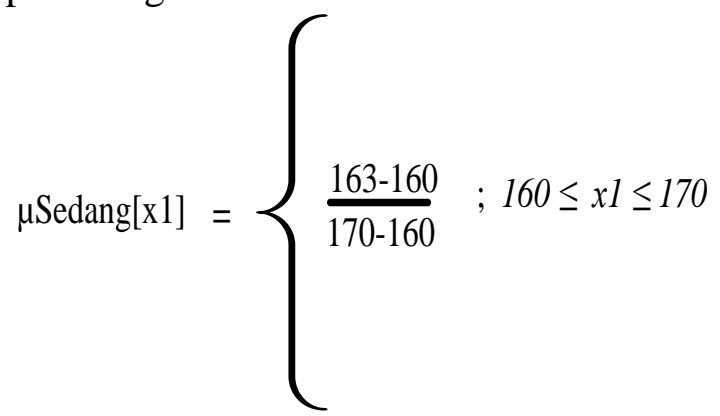

$\mu$ Sedang $[\mathrm{x} 1]=3 / 10$

$\mu$ Sedang $[\mathrm{x} 1]=0.30$ 
3. Variabel Umur $=19$ termasuk dalam keanggotaan Sangat Muda dengan perhitungan:

$\mu$ Sangat Muda $[\mathrm{x} 1]=\left\{\frac{19-19}{21-19} ; 19 \leq x 1 \leq 21\right.$

$\mu$ Sangat Muda $[\mathrm{x} 1]=0 / 2$

$\mu$ Sangat Muda $[\mathrm{x} 1]=0.00$

Tahap 2: Inference Rule

Adapun pada inference rule untuk pengujian kasus pertama ini menggunakan 3 rule yaitu :

[R1=]Jika Nilai IPK=Sedang, Tinggi=Rendah, Usia=Muda maka keputusan Tidak Diterima.

[R2]=Jika Nilai IPK= Sedang, Tinggi Badan=Tinggi, Umur=Sangat Muda maka keputusan Diterima.

[R3]=Jika Nilai IPK=Sedang, Tinggi Badan=Sedang, Umur=Sangat Muda maka keputusan Dipertimbangkan.

Rule 1: Z1 = $\min$ ( $\mu$ sedang(3.2), $\mu$ rendah(159), $\mu$ muda(26))

$$
\begin{aligned}
& =\min (0.60,0.57,0.60) \\
& =0.57
\end{aligned}
$$

Agregation dari rule 1 dapat dilihat pada gambar 5 .

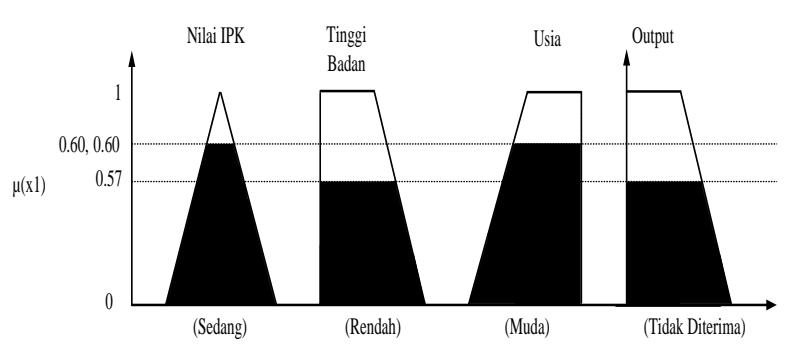

Gambar 5 : Agregation Rule 1

Rule 2: $\mathrm{Z1}=\min$ ( $\mu$ sedang(2.95), $\mu$ tinggi(168), $\mu$ sangat muda(19))

$$
\begin{gathered}
=\min (0.27,0.08, .00) \\
=0.00
\end{gathered}
$$

Agregation dari rule 2 dapat dilihat pada gambar 6.

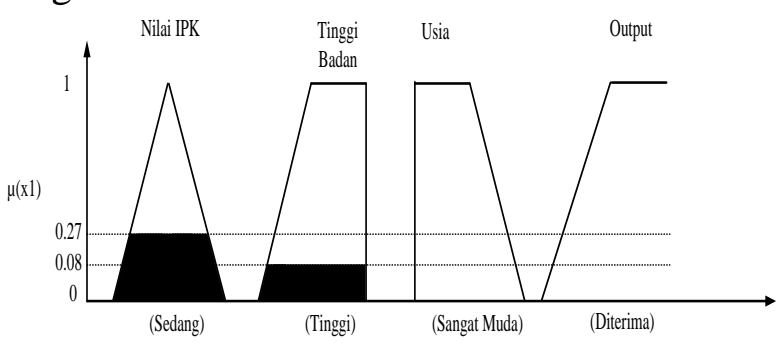

Gambar 6 : Agregation Rule 2

Rule 3: $\mathrm{Z1}=\mathrm{min}$ ( $\mu$ sedang(2.9), $\mu$ sedang(169), $\mu$ sangat muda(19))

$$
\begin{aligned}
& =\min (0.20,0.15,0.00) \\
& =0.00
\end{aligned}
$$

Agregation dari rule 3 dapat dilihat pada gambar 7.

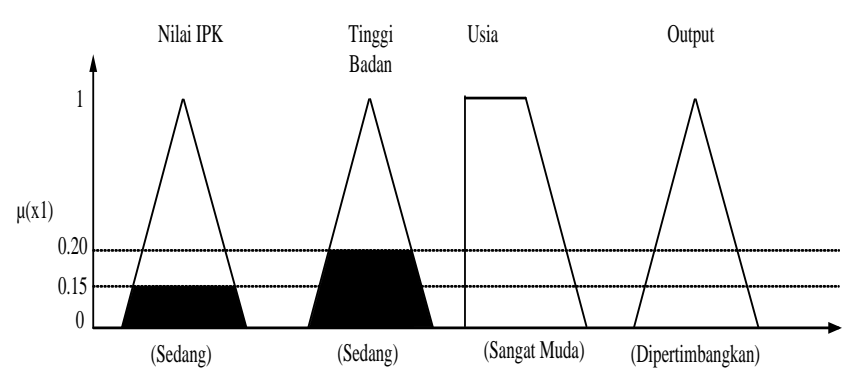

Gambar 7 : Agregation Rule 3

Dari hasil aplikasi fungsi implikasi dari tiap aturan, digunakan metode max-min untitak melakukannimkromposisi anttar semua fturan. Hasil dari combination dapat

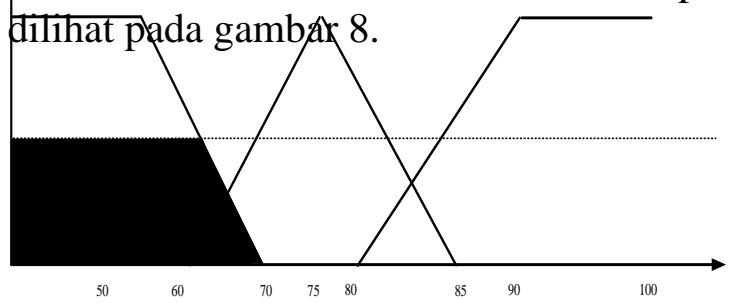

\section{Gambar 8 : Combination Kasus 1}

Tahap 3 : Defuzifikasi

Setelah melakukan inference rule, tahapan selanjutnya melakukan defuzifikasi, dapat dilihat pada analisa berikut ini, dengan menggunakan metode Center Off Average 


\begin{tabular}{|c|c|c|c|}
\hline Kode & Pertanyaan & Jawaban & Rule \\
\hline A1 & Nilai IPK & $\begin{array}{l}\text { Nilai } \\
\text { IPK } \\
>=2.75\end{array}$ & $\begin{array}{l}\text { Jika } \\
\text { A1="Nilai } \\
\text { IPK" >=2.75 }\end{array}$ \\
\hline A2 & $\begin{array}{l}\text { Tinggi } \\
\text { Badan }\end{array}$ & $\begin{array}{l}\text { Tinggi } \\
\text { Badan } \\
>=155\end{array}$ & $\begin{array}{l}\text { dan } \\
\text { A2="Tinggi } \\
\text { Badan">=155 }\end{array}$ \\
\hline A3 & Usia & $\begin{array}{l}\text { Usia } \\
<=25\end{array}$ & $\begin{array}{l}\text { A3="Usia" } \\
<=25 \text { maka } \\
\text { keputusan } \\
\text { Lulus Seleksi } \\
\text { Administrasi }\end{array}$ \\
\hline
\end{tabular}

(COA), maka keputusannya adalah sebagai berikut :

$\mathrm{Z}=50 * 0.57+60 * 0.57+70 * 0.57+75 * 0.00+8$

$0 * 0.00+85 * 0.00+90 * 0.00+100 * 0.00$

$0.57+0.57+0.57+0.00+0.00+0.00+0.00+0$. 00

\begin{tabular}{llll}
\hline Kode & Pertanyaan & Jawaban & Rule \\
\hline B1 & Penampilan & $1 / 2 / 3 / 4$ & $\begin{array}{l}\text { Jika } \\
\text { B1="Penam } \\
\text { pilan">=2 } \\
\text { dan }\end{array}$ \\
B2 & Wawasan & $1 / 2 / 3 / 4$ & an" $>=2$ dana \\
& & & $\begin{array}{l}\text { B3="Karakt } \\
\text { er">=2 } \\
\text { Maka } \\
\end{array}$ \\
& & & keputusan \\
B3 & Karakter & $1 / 2 / 3 / 4$ & Lulus \\
& & & \\
& & & \\
\hline
\end{tabular}

$\mathrm{Z}=28.57+34.29+40.00+0.00+0.00+0.00+0$ $.00+0.00$

1.71

$\mathrm{Z}=\frac{102.86}{1.71}$

$\mathrm{Z}=60.00$

Untuk hasil nilai perhitungan dengan rule nilai $\mathrm{IPK}=2.9$, Tinggi Badan $=160$, dan Usia=19 maka calon pegawai tersebut dinyatakan Dipertimbangkan.

Perancangan Rule

Pada bagian ini menjelaskan rule-rule yang dirancang dalam pembuatan sistem untuk masing-masing parameter input.

Rule Seleksi Administrasi

Pada tahapan seleksi administrasi adapun yang menjadi parameter untuk penyeleksian yaitu nilai IPK, Tinggi Badan, Usia dan rule yang dibentuk sebagai berikut :

Rule :

IF Nilai IPK $>=2,75$ and Tinggi Badan $>=155$ and Usia $<=25$ THEN keputusan Lulus.

Daftar aturan rule untuk seleksi dokumen dapat dilihat pada tabel 1 .

\section{Tabel 1 : Daftar Aturan Untuk Lulus Seleksi Dokumen}

Rule Tes Intial Interview dan Interview Akhir

Setelah calon pegawai dinyatakan lulus tahapan seleksi administrasi, tahapan selanjutnya yaitu seleksi tes initial interview dengan ketetapan rule sebagai berikut:

Rule :

IF Penampilan $>=2$ and Wawasan $>=2$ and Karakter $>=2$ THEN keputusan Lulus.

Daftar aturan rule untuk tes Initial Interview dapat dilihat pada tabel 2.

\section{Tabel 2. Daftar Aturan Untuk Lulus Initial Interview}

Rule Tes Psikotes

Tahap ke 3 untuk seleksi penerimaan pegawai yaitu tes psikotes apabila calon pegawai tersebut telah lulus tes Initial Interview. Adapun rule-rule untuk tes psikotes yaitu :

Rule :

IF intelegency=Disarankan or Masih Dapat Disarankan and Minat=Disarankan or Masih Dapat Disarankan and Bakat=Disarankan or Masih Dapat Disarankan and Kepribadian=Disarankan or Masih Dapat Disarankan THEN Keputusan Lulus.

Daftar aturan rule untuk lulus tes Psikotes dapat dilihat pada tabel 3 . 


\begin{tabular}{|c|c|c|c|c|}
\hline \multirow{2}{*}{ Kode } & \multirow{2}{*}{ Pertanyaan } & \multicolumn{2}{|c|}{ Jawaban } & \multirow{2}{*}{ Rule } \\
\hline & & 1 & 2 & \\
\hline D1 & $\begin{array}{l}\text { Kesehatan } \\
\text { Jasmani }\end{array}$ & $\checkmark$ & $\square$ & \multirow{3}{*}{$\begin{array}{l}\text { Jika D1= } \\
\text { "SEHAT" } \\
\text { dan D2= } \\
\text { "SEHAT" } \\
\text { dan D3= } \\
\text { "TIDAK" } \\
\text { maka } \\
\text { keputusan } \\
\text { Lulus. }\end{array}$} \\
\hline D2 & $\begin{array}{l}\text { Kesehatan } \\
\text { Rohani }\end{array}$ & $\checkmark$ & $\square$ & \\
\hline D3 & Narkotika & $\square$ & $\checkmark$ & \\
\hline
\end{tabular}

Tabel 3 : Daftar Aturan Untuk Lulus Tes Psikotes

Keterangan :

DS =Disarankan

MDS =Masih Dapat Disarankan

TDS =Tidak Dapat Disarankan

Rule Tes Kesehatan

Tahapan ke 4 untuk seleksi penerimaan pegawai yaitu tes kesehatan, adapun rulerule untuk tes kesehatan sebagai berikut :

Rule :

IF Kesehatan Jasmani=SEHAT and Kesehatan Rohani=SEHAT and Narkotika=TIDAK THEN Keputusam Lulus.

Daftar aturan rule untuk lulus tes Kesehatan dapat dilihat pada tabel 4 .

\section{Tabel 4 : Daftar Aturan Untuk Lulus Tes Kesehatan}

Keterangan :

$1 \quad=$ Sehat

$2 \quad=$ Tidak

Pengujian dan Implementasi Sistem

Langkah awal yang dilakukan sebelum membuat program, terlebih dahulu dirancang database dengan menggunakan mysql. Pada mysql dibuat tabel-tabel yang dibutuhkan, seperti tabel user, pendaftaran, initial interview, psikotes, dan tes kesehatan. Setelah dilakukan perancangan database yang dibutuhkan, selanjutnya dirancang form-form yang dibutuhkan. Salah satu fungsi dari form ini adalah sebagai interface antara user (pengguna) dengan sistem. Setelah semua form yang dibutuhkan selesai langkah selanjutkan

\begin{tabular}{|c|c|c|c|c|c|}
\hline \multirow[b]{2}{*}{ Kode } & \multirow[b]{2}{*}{ Pertanyaan } & \multicolumn{3}{|c|}{ Jawaban } & \multirow[b]{2}{*}{ Rule } \\
\hline & & $\begin{array}{l}\text { D } \\
\text { S }\end{array}$ & $\begin{array}{l}\text { M } \\
\text { D } \\
\text { S }\end{array}$ & $\begin{array}{l}\text { T } \\
\text { D } \\
\text { S }\end{array}$ & \\
\hline $\mathrm{C} 1$ & Intelegency & $\checkmark$ & $\checkmark$ & & \multirow{4}{*}{$\begin{array}{l}\text { Jika } \\
\mathrm{C} 1=" \mathrm{DS} / \mathrm{M} \\
\mathrm{DS} " \\
\text { dan } \\
\mathrm{C} 2=" \mathrm{DS} / \mathrm{M} \\
\mathrm{DS} " \\
\text { dan } \\
\mathrm{C} 3=" \mathrm{DS} / \mathrm{M} \\
\mathrm{DS} " \\
\text { dan } \\
\text { C4="DS/M } \\
\text { DS" } \\
\text { maka } \\
\text { keputusan } \\
\text { Lulus. }\end{array}$} \\
\hline $\mathrm{C} 2$ & Minat & $\checkmark$ & $\checkmark$ & & \\
\hline $\mathrm{C} 3$ & Bakat & $\checkmark$ & $\checkmark$ & & \\
\hline $\mathrm{C} 4$ & Kepribadian & $\checkmark$ & $\checkmark$ & & \\
\hline
\end{tabular}

semua data sampel akan diinputkan ke dalam sistem dan tersimpan dalam database. Langkah akhir dilakukan adalah melakukan pengolahan data melalui form hasil keputusan. Adapun form hasil keputusan dapat dilihat pada gambar 9 .

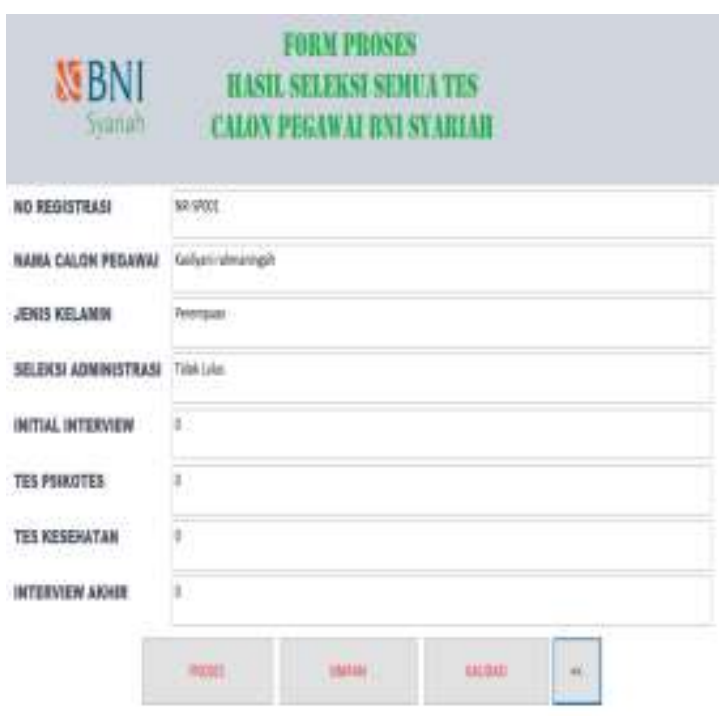

\section{Gambar 9 : Form Hasil Keputusan}

Setelah dilakukan proses pada form hasil seleksi maka semua data calon pegawai akan tersimpan pada database, dan pada laporan akan muncul data semua seleksi 
sehingga akan mendapatkan informasi berupa keputusan. Untuk laporan keputusan dapat dilihat pada gambar 10.

\begin{tabular}{|c|c|c|c|c|}
\hline \multicolumn{5}{|c|}{ WBNI BNISYARIAH } \\
\hline No & No Angistrmt: & Nama Catoe Prograi & $\begin{array}{c}\text { Jenis } \\
\text { Ketiamin }\end{array}$ & Keputusan \\
\hline 1 & Ne-seot & Sevilumi atmaringeit & Barenteras & neak Detorime \\
\hline 2 & Nestopt & 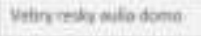 & Perempian & Thene Diterina \\
\hline 3 & Nes spoves & Almopeh sutra & Lati-gabi & Titak Dimerima \\
\hline$a$ & Mestoon & Deligrsiemtian & Peremsuar & Duprtimbandan \\
\hline 5 & Nestraves & 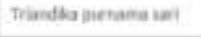 & Fermenoum & 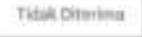 \\
\hline 11 & tatspose & Aieviamantets & Laticai & nata Diarlas: \\
\hline 2 & NeSPODI & le huseritu & Perenoumen & Dipertimbande= \\
\hline . & neespoot & Dteabischinta & Menneviar & Thea beries \\
\hline 9 & Nh:SAan & Saries mulifarter & Beremouas & That Daterine \\
\hline III & Mesweis & has nopers ani & Permenums & Thatistaries \\
\hline nI & nesponit & Masulatipen & Pernaguas & 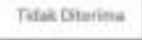 \\
\hline 12 & Nen sNon2 & Antinuteari & Drimmias & 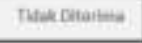 \\
\hline $\mathrm{a}$ & Nespes] & feterianunise & Disenoum & That Dierient \\
\hline 14 & Me we14 & Hettrenasids & Astantevias & Civentintheryos \\
\hline 15 & Nessens & 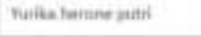 & Bermenam & Thise Cisarima \\
\hline the & wescous & 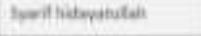 & Laillaki & Dipentimberste- \\
\hline
\end{tabular}

Gambar 10 : Laporan Keputusan SPK SIMPULAN

Berdasarkan pembahasan dan hasil pengujian aplikasi ini, maka dapat dibuat kesimpulan antara lain:

1. Sistem Pendukung Keputusan penerimaan calon pegawai dapat memudahkan dalam pengambilan keputusan untuk menentukan calon pegawai BNI Syariah yang akan dipilih.

2. Dengan menggunakan metode logika fuzzy, proses untuk menentukan kelayakan calon pegawai diterima atau tidak lebih mudah dibandingkan dengan menggunakan cara manual, karena sistem langung memberikan hasil berupa keputusan.

\section{DAFTAR PUSTAKA}

[1] Susan, E. (2019). Manajemen sumber daya manusia. Adaara: Jurnal Manajemen Pendidikan Islam, 9(2), 952-962.
[2] Safrizal, S., \& Susianto, S. (2019). Pengembangan Model Sistem Pendukung Keputusan Dengan Kombinasi Metode Fuzzy Tahani Dan Topsis Dalam Penilaian Kinerja Instruktur. J-SAKTI (Jurnal Sains Komputer dan Informatika), 3(2), 227-242.

[3] Kusrini, K. (2007). Aplikasi Sistem Pendukung Keputusan. Yogyakarta: Andi.

[4] Ohri, A., \& Singh, P. K. (2010). Development of decision support system for municipal solid waste Management in India: A review. International journal of environmental sciences, 1(4), 440-453.

[5] Turban, E. Dkk. 2005. Decision Support systems and Intelligent Systems Edisi, 7.

[6] Christioko, B. V., Indriyawati, H., \& Hidayati, N. (2017). Fuzzy MultiAtribute Decision Making (Fuzzy MADM) dengan Metode SAW untuk Pemilihan Mahasiswa Berprestasi. Jurnal Transformatika, 14(2), 82-85.

[7] Kusumadewi, S., \& Purnomo, H. (2004). Aplikasi logika. Fuzzy untuk Pendukung keputusanedisi kedua.

[8] Asrori, M., \& Falani, A. Z. (2019). IMPLEMENTASI PENENTUAN PEMBERIAN TUNJANGAN PENDIDIK \& TENAGA KEPENDIDIKAN BERBASIS FUZZY DATABASE MODEL TAHANI. Insand Comtech: Information Science and Computer Technology Journal, 4(2).

[9] Intan, I., Fatmasari, F., \& Wahyuni, S. (2019, December). APLIKASI PENCARIAN KAFE MENGGUNAKAN METODE FUZZY BERDASARKAN KRITERIA PILIHAN PENGGUNA BERBASIS SISTEM INFORMASI GEOGRAFIS PADA MOBILE ANDROID. In sensitif: Seminar 
Nasional Sistem Informasi dan Teknologi Informasi (pp. 1043-1054). [10] Muhammad, A., \& Gusrianty, G. (2019). Pengembangan Aplikasi Penilaian Kinerja Guru di Sekolah Menengah Pertama (SMP) Menggunakan Logika Fuzzy (Studi Kasus: SMP Negeri 3 Mandau). Jurnal Mahasiswa Aplikasi Teknologi Komputer dan Informasi (jmapteksi), 1(1), 46-51.

[11] Alfath, S., Marisa, F., \& Wijaya, I. D. (2019). PENENTUAN PERINGKAT SOFT SKILL SISWA MENGGUNAKAN METODE FUZZY TAHANI STUDI KASUS SDN 1 PANDANSARI LOR. Jurnal SPIRIT, 11(2).

[12] Hariandi, R., Putra, D., \& Novalina, S. (2020). SISTEM PENDUKUNG KEPUTUSAN PENYELEKSIAN PEGAWAI NEGERI SIPIL (PNS) PROFESIONAL MENGGUNAKAN METODE FUZZY MCDM. Jursima, 8(1), 32-37.

[13] Ikhwan, A. (2019). Penerapan Fuzzy Mamdani Untuk Sistem Pendukung Keputusan Pemilihan Laptop. JURNAL FASILKOM, 9(2), 476-483.

[14] Mutiara, S., \& Aziz, R. A. (2019). SISTEM PENDUKUNG KEPUTUSAN PEMILIHAN KONSENTRASI BIDANG ILMU EKONOMI MENGGUNAKAN METODE WEIGHTED AVERAGE DAN FUZZY FIS TSUKOMOTO (Studi Kasus Program Magister Manajemen IIB Darmajaya). Jurnal Informatika, 19(2), 167-179.

[15] Yudara, I. G., \& Sugiartawan, P. (2019). Sistem Pendukung Keputusan Penentuan Pegawai Terbaik Menggunakan Metode Fuzzy AHP. Jurnal Sistem Informasi dan
Komputer Terapan Indonesia (JSIKTI), 1(4), 215-224.

[16] Julianto, V. (2020). Analisis Sistem Pendukung Keputusan Evaluasi Kualitas Mengajar Dosen Menggunakan Metode Fuzzy AHP dan SAW. Jurnal Sains dan Informatika, 6(1). 